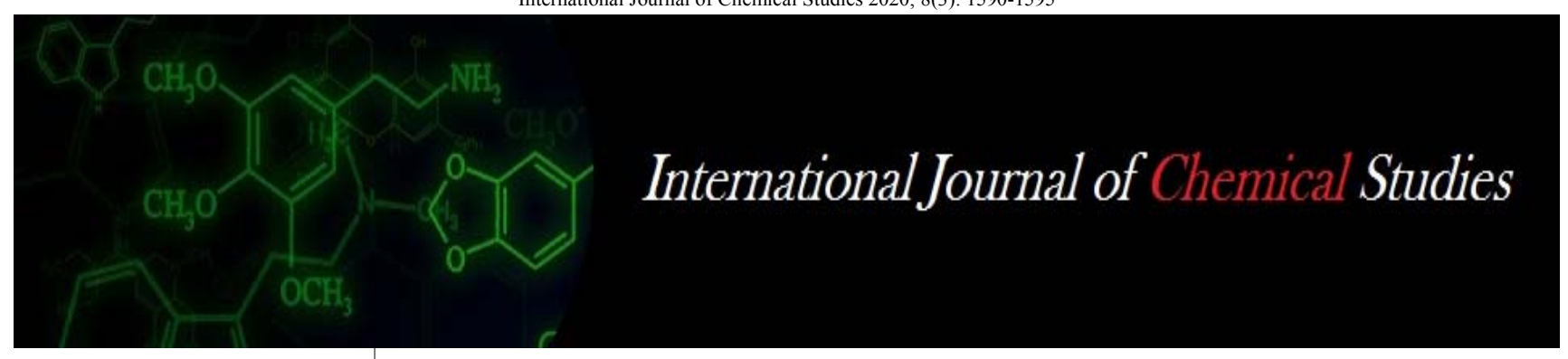

P-ISSN: 2349-8528 E-ISSN: 2321-4902 www.chemijournal.com IJCS 2020; 8(3): 1590-1595 (C) 2020 IJCS

Received: 19-03-2020 Accepted: 22-04-2020

Pallavi N Bansod Ph. D. Scholar, Department of Horticulture, Mahatma Phule Krishi Vidyapeeth, Rahuri, Maharashtra, India

\section{Ekta Ningot}

Assistant Professor,

Horticulture Section,

College of Agriculture,

Nagpur, Maharashtra, India

Sanjivani P Gondane Ph. D. Scholar, Department of Horticulture, Mahatma Phule Krishi Vidyapeeth, Rahuri, Maharashtra, India
Corresponding Author: Pallavi N Bansod Ph. D. Scholar, Department of Horticulture, Mahatma Phule Krishi Vidyapeeth, Rahuri, Maharashtra, India

\section{Biochemical and sensory evaluation of cookies produced from Aerial yam (Dioscorea bulbifera L.) flour}

\author{
Pallavi N Bansod, Ekta Ningot and Sanjivani P Gondane
}

DOI: https://doi.org/10.22271/chemi.2020.v8.i3v.9421

\section{Abstract}

A study was carried out at Post Harvest Laboratory, Department of Horticulture, Dr. Panjabrao Deshmukh Krishi Vidyapeeth, Akola during the year 2016-17. Cookies were produced from aerial yam and wheat flour blends. Aerial yam was processed into flour and used to substitute wheat flour at different proportions (20\% aerial yam flour: $80 \%$ wheat flour, $40 \%$ aerial yam flour: $60 \%$ wheat flour, $60 \%$ aerial yam flour: $40 \%$ heat flour, $80 \%$ aerial yam flour: $20 \%$ wheat flour, $100 \%$ aerial yam flour ) and $100 \%$ wheat flour as control. The experiment was laid out in Randomized Block Design with four replication, the cookies were analyzed for biochemical and sensory attributes. From findings it was observed that, the increase in aerial yam flour increased the percentage of moisture, ash, fat and crude fibre content of cookies while protein and carbohydrate content was decreased. The sensory attributes (appearance, taste, texture, flavor and crispiness) were evaluated for acceptability of yam cookies with the help of score card by panel of judges. From the sensory evaluation, the treatment with $60 \%$ aerial yam flour $+40 \%$ wheat flour had highest overall acceptability. It was also found to be the most acceptable with respect to organoleptic characters especially taste and flavor/aroma developed during baking as compared to other treatments.

Keywords: Aerial yam, cookies, biochemical properties and sensory evaluation.

\section{Introduction}

Roots and tuber crops such as yams, cassava, cocoyam and sweet potatoes rank next in importance to the cereals grains in providing the major part of the daily coloric needs of people in the tropics (Ihekoronye and Ngoddy, 1985) ${ }^{[8]}$. Yam makes a major contribution to the nutrition of West Africans as a source of carbohydrate, before the introduction of cassava and sweet potatoes. Yams serve as major contributor to food security in West Africa (Zannou, 2006) ${ }^{[25]}$, but out of the over 600 known yam species, only seven are mostly consumed (Jayakody et al., 2007) ${ }^{[9]}$. These include Dioscorea rotundata Poir (White yam), Dioscorea cayenensis (Yellow yam), Dioscorea alata (Water yam), Dioscorea bulbifera (Aerial yam), Dioscorea esculenta, Dioscorea praehensalis (Bush yam) and Dioscorea dumetorum (Bitter yam). D. rotundata is the most important species grown and consumed in Ghana, in terms of area planted and quantity produced (Otoo and Asiedu, 2008) ${ }^{[17]}$.

Aerial yam (Dioscorea bulbifera L.) also known as potato yam, creeky yam (Ojinnaka et al., 2016) ${ }^{[13]}$ is a species of yam grown throughout the world. This bulbils bearing yam belongs to the family Dioscoreaceae is unpopular among the edible yam species. Their tubers are used by the tribal population of central India as food particularly in Madhya Pradesh, Chhattisgarh, Jharkhand and Orissa (Subasini et al., 2013) ${ }^{[22]}$. In Maharashtra it is grown as a minor vegetable crop of bulbous group in high rainfall area of Konkan and eastern Vidarbha zone (EVZ). In Konkan region it is called as "karanda" whereas "mataru" in EVZ.

Aerial yam produces aerial bulbs which look like potatoes. Its composition includes 63-67 per cent moisture, 1.1-1.5 per cent proteins, 0.04 per cent fat, 0.7-1.1 per cent fibre, 1.08-1.5 per cent ash and 22-33 per cent carbohydrates (Nwosu, 2014) ${ }^{[12]}$. It is a good source of calories and minerals such as iron, calcium and phosphorous (Tindall, 1983 and Abara et al., 2000) [23, 3]. "Diosgenin" is pharmacologically active component of aerial yam obtained from root and rhizomes which is one of the most costly and important steroidal drug used worldwide for manufacturing of birth control pills and other steroidal formulations (Sharma, 2004) ${ }^{[21]}$. 
Aerial yam bulbs can be prepared and processed into edible food by boiling, freezing or roasting. It can be processed to various forms such as crisps, chips or flakes and can be converted into shelf stable and convenient forms such as flours (Nwosu, 2014) ${ }^{[12]}$. This flour can be used in combination with different flours obtained from root, tubers, cereals and legumes crops to form composite flour. Flour prepared from aerial yam bulbs has the potential for application in the bakery industry with minimal processing. Therefore, investigation into the nutritional and other quality characteristics of the aerial yam is essential, with the ultimate aim being the promotion of its usage, and suggesting possible product that it could be incorporated into, since aerial yam has received very low attention by food processors and consumers. This study seeks to investigate the possibility of preparation of cookies from aerial yam flour with good acceptability.

\section{Material and Method}

The raw materials

Aerial yam bulbs were procured from the local market of Gadchiroli, Maharashtra. Wheat flour and other ingredients i.e. sugar, hydrogenated fat, sodium bicarbonate (baking powder), butter, milk powder and cardamom were purchased from local market of Akola.

\section{Preparation of composite flour}

The composite flour was prepared by mixing aerial yam flour and wheat flour at different levels given below.

Table 1: Formulation of composite flour of aerial yam and wheat for preparation of cookies

\begin{tabular}{|c|c|c|}
\hline Treatments & Aerial yam flour (g) & Wheat flour (g) \\
\hline $\mathrm{T}_{1}$ (AYF $20 \%+$ WF $\left.80 \%\right)$ & 100 & 400 \\
\hline $\mathrm{T}_{2}$ (AYF $40 \%+$ WF $\left.60 \%\right)$ & 200 & 300 \\
\hline $\mathrm{T}_{3}$ (AYF $60 \%+$ WF $\left.40 \%\right)$ & 300 & 200 \\
\hline $\mathrm{T}_{4}(\mathrm{AYF} 80 \%+$ WF $20 \%)$ & 400 & 100 \\
\hline $\mathrm{T}_{5}(\mathrm{AYF} 100 \%)$ & 500 & 0 \\
\hline $\mathrm{T}_{6}($ WF $100 \%)$ & 0 & 500 \\
\hline
\end{tabular}

\section{Preparation of cookies}

Cookies were prepared using AACC (2000) ${ }^{[1]}$ methods. Various ingredients were weighed accurately. The hydrogenated fat and powdered sugar were creamed until light and fluffy. The composite flour was slowly added to the cream. The traditional creaming method was used for the preparation of cookies. The dough was thoroughly kneaded by adding required amount of water dissolved with sodium bicarbonate. After kneading the dough was rolled between polyethylene sheet having thickness of $1-1.2 \mathrm{~cm}$ and pieces was cut using cookie cutter. The pieces were placed in baking tray smeared with fat and baked at $180-200^{\circ} \mathrm{C}$, for 15 minutes in baking oven. The cookies were allowed to cool, packed in HDPE bags.

\section{Chemical analysis of flour and cookies}

Aerial yam flour and its cookies were evaluated for its proximate composition viz. moisture, fat, protein, ash and carbohydrate content using standard method (AOAC, 1995) ${ }^{[2]}$.

\section{Moisture content (\%)}

About $5 \mathrm{~g}$ of sample was weighed and transferred to predried, covered dish. Weighed sample was then dried in hot air oven at $105 \pm 1{ }^{\circ} \mathrm{C}$ for $4 \mathrm{hrs}$. The dish with dried sample was transferred to the desiccator and cooled to room temperature.
The dish was then weighed. Moisture content in per cent was calculated from loss in weight.

$$
\text { Moisture }(\%)=\frac{\left(\mathrm{W}_{1}-\mathrm{W}_{2}\right)}{\mathrm{W}_{1}-\mathrm{W}} \times 100
$$

Where,

$\mathrm{W}_{1}=$ Weight $(\mathrm{g})$ of the dish with the material before drying

$\mathrm{W}_{2}=$ Weight $(\mathrm{g})$ of the dish with the material after drying

$\mathrm{W}=$ Weight $(\mathrm{g})$ of the empty dish

\section{Fat}

The fat content was determined by the ether extraction using Soxhlet's apparatus.

\section{Reagent}

Petroleum ether having a boiling point of $40-60^{\circ} \mathrm{C}$.

\section{Procedure}

About $5 \mathrm{~g}$ powder sample was taken on filter paper and made a suitable size packet. The packet was placed in extraction flask of Soxhlet's unit and attached to collecting flask. One and half spoonful of solvent was poured through extraction flask into pre-weighed collecting flask. Assembly condenser was connected to tap water and the flask was heated at $60^{\circ} \mathrm{C}$. Sample with 6-8 siphoning was extracted and most of the solvent was distilled off to extraction flask. The collecting flask was dried on water bath and then at $100^{\circ} \mathrm{C}$ for $1 \mathrm{hr}$ in oven. The flask was cooled and weighed. Increase in weight of flask represented crude fat content. Per cent fat content in the sample was calculated using formula.

$$
\text { Fat }(\%)=\frac{\text { Weight of fat }(\mathrm{g})}{\text { Weight of sample }(\mathrm{g})} \times 100
$$

\section{Protein}

The protein content was determined by Micro-kjeldahl's apparatus.

\section{Reagents}

1. N- Free sulphuric acid

2. Hydrogen peroxide $(30 \%)$

3. Boric acid (4\%)

4. Sodium hydroxide (50 \%) containing sodium thiosulphate $(5 \%)$

5. Catalyst mixture (potassium sulphate $9.9 \mathrm{~g}$, mercuric oxide $0.41 \mathrm{~g}$, copper sulphate $0.8 \mathrm{~g}$ ).

6. Mixed indicator (Dissolved separately $0.2 \%$ each of bromo-cresol green and methyl red indicators in $95 \%$ ethyl alcohol and mixed together in 5:1, respectively and transferred to bottle provided with stopper).

7. Standard hydrochloric acid (Diluted $0.17 \mathrm{ml}$ concentration $\mathrm{HCl}$ to $100 \mathrm{ml}$ with water and checked the concentration against $0.02 \mathrm{~N}$ sodium hydroxide).

\section{Procedure}

About $0.2 \mathrm{~g}$ defatted powder sample was taken and transferred to the digestion flask. The catalyst mixture (1g) and $5 \mathrm{ml}$ each of $\mathrm{H}_{2} \mathrm{O}_{2}$ and conc. $\mathrm{H}_{2} \mathrm{SO}_{4}$ were added carefully. The sample was digested until it became colour less by frequent rotating the flask. The flask was cooled and a $5 \mathrm{ml}$ portion of water was slowly added with mixing. After cooling, the content was transferred to $50 \mathrm{ml}$ volumetric flask with 2-3 rinsing, and the volume was made up with distilled water and mixed thoroughly. Blank digestion was carried out 
simultaneously. The distillation unit was cleaned by starting and sucking back the water. The beaker of $100 \mathrm{ml}$ capacity containing $10 \mathrm{ml}$ boric acid, 4 drops of indicator was taken and placed under condenser with its tip dipped in solution. The digest $(5 \mathrm{ml})$ with rinsing was transferred to distillation flask, $5 \mathrm{ml} \mathrm{NaOH}$ was added and closed with stop cork. The digest was allowed to boil and about $50 \mathrm{ml}$ distillate of ammonia liberated in boric acid was collected. The distillate was titrated with hydrochloric acid until blue colour disappeared. Blank titration was carried out simultaneously. Protein content was calculated using following formula.

$$
\mathrm{N}(\%)=\frac{(\mathrm{S}-\mathrm{B}) \times \mathrm{N} \times 14.007}{\text { Weight of sample }(\mathrm{g})} \times \frac{\text { Volume made }(\mathrm{ml})}{\text { Volume taken }(\mathrm{ml})} \times 100
$$

Where,

$\mathrm{S}=\mathrm{ml}$ of $\mathrm{HCl}$ required for sample titration

$\mathrm{B}=\mathrm{ml}$ of $\mathrm{HCl}$ required for blank titration

$\mathrm{N}=$ Normality of $\mathrm{HCl}(0.02 \mathrm{~N})$

Protein $(\%)=$ Nitrogen $(\%) \times 6.25$

\section{Crude fibre}

\section{Reagent}

1. Sulphuric acid $(0.255 \mathrm{~N})$

2. Sodium hydroxide $(0.313 \mathrm{~N})$

3. Potassium sulphate (10\% solution)

\section{Procedure}

About $2 \mathrm{~g}$ fat free residue was taken and then transferred to the digestion flask. $200 \mathrm{ml}$ boiling sulphuric acid was added and immediately the flask was connected to condenser. The flask was heated, boiled by frequently rotating for $30 \mathrm{~min}$ and the volume was maintained with hot water. Then filtered through filter cloth in fluted funnel. The residue was washed on cloth with hot water or potassium sulphate solution. The residue was returned to digestion flask by washing with hot water, $200 \mathrm{ml}$ boiling sodium hydroxide was added and boiled for $30 \mathrm{~min}$. The volume was adjusted with boiling water, filtered it through the muslin cloth and the residue free of alkali was washed. The residue was transferred into crucible and washed with $15 \mathrm{ml}$ alcohol and the crucible was dried at $110{ }^{\circ} \mathrm{C}$ for $2 \mathrm{hrs}$. The crucible was cooled in desiccator and weighed. The crucible was ignited in the furnace at $550{ }^{\circ} \mathrm{C}$ for $30 \mathrm{~min}$. then cooled and weighed. The loss in weight represented the crude fibre.

$$
\text { Crude fibre }(\%)=\frac{\left(\mathrm{W}_{1}-\mathrm{W}_{2}\right)}{\text { Weight of sample }(\mathrm{g})} \times 100
$$

Where,

$\mathrm{W}_{1} \quad$ = Weight of material before ashing $(\mathrm{g})$

$\mathrm{W}_{2} \quad=$ Weight of material after ashing $(\mathrm{g})$

\section{Ash}

About $5 \mathrm{~g}$ of the powder sample was accurately weighed into a pre-weighed silica crucible. It was then carbonized in silica crucible on burner followed by heating at about $600{ }^{\circ} \mathrm{C}$ for 6 hrs in the muffle furnace to get complete white coloured ash, allowed to cool in the furnace. Then the crucible was transferred to a desiccator and weighed as possible to prevent moisture absorption. The ash was calculated using following formula.

$$
\text { Ash }(\%)=\frac{\text { Weight of ash }(\mathrm{g})}{\text { Weight of sample }(\mathrm{g})} \times 100
$$

\section{Carbohydrates}

Carbohydrates were calculated by difference method as follows.

Carbohydrate $(\%)=100-($ Moisture + Fat + Protein + Ash + Crude fibre $) \%$

\section{Sensory evaluation}

The cookies were evaluated for the sensory parameters using standard procedure reported by Amerine et al. (1965). The cookies were evaluated for sensory attributes by a panel of 5 expert judges, using a 9 point Hedonic scale ranging from like extremely to dislike extremely for different parameters. The mean values of score for appearance, taste, texture, flavor/aroma and overall acceptability were calculated.

\section{Statistical analysis}

The data obtained for each parameter was subjected to statistical analysis of variance (ANOVA) within the treatments. The comparison of mean was carried out by randomized block design for significance of SE and CD at 5 per cent level as suggested by Panse and Sukhatme (1985).

\section{Result and discussion}

Biochemical properties of cookies

The results of the effect of different flour combination of aerial yam on moisture, ash, fat, protein, crude fibre and carbohydrate content of cookies are presented in Table 2 .

Table 2: Effect of different flour combination of aerial yam on biochemical properties of cookies.

\begin{tabular}{|c|c|c|c|c|c|c|}
\hline Treatments & Moiture & Ash & Fat & Protein & Crude fibre & Carbohydrate \\
\hline $\mathrm{T}_{1}(\mathrm{AYF} 20 \%+$ WF $80 \%)$ & 4.41 & 1.24 & 21.08 & 8.92 & 0.78 & 63.57 \\
\hline $\mathrm{T}_{2}(\mathrm{AYF} 40 \%+$ WF 60\%) & 4.39 & 1.37 & 22.23 & 8.32 & 1.02 & 62.67 \\
\hline $\mathrm{T}_{3}(\mathrm{AYF} 60 \%+$ WF 40\%) & 4.87 & 1.51 & 23.34 & 7.72 & 1.27 & 61.29 \\
\hline $\mathrm{T}_{4}(\mathrm{AYF} 80 \%+$ WF 20\%) & 5.36 & 1.63 & 24.48 & 7.13 & 1.51 & 59.86 \\
\hline $\mathrm{T}_{5}(\mathrm{AYF} 100 \%)$ & 5.83 & 1.76 & 25.64 & 6.53 & 1.75 & 58.49 \\
\hline $\mathrm{T}_{6}(\mathrm{WF} 100 \%)$ & 3.42 & 1.10 & 19.98 & 9.51 & 0.54 & 65.45 \\
\hline 'F' test & Sig. & Sig. & Sig. & Sig. & Sig. & Sig. \\
\hline SE(m) \pm & 0.003 & 0.005 & 0.002 & 0.003 & 0.006 & 0.018 \\
\hline CD at 5\% & 0.008 & 0.015 & 0.005 & 0.008 & 0.02 & 0.056 \\
\hline
\end{tabular}

\section{Moisture content (\%)}

The treatment $\mathrm{T}_{5}$ (AYF 100\%) showed maximum (5.83\%) moisture which was found significantly superior over remaining treatments, while minimum $(3.42 \%)$ moisture was recorded in $\mathrm{T}_{6}(\mathrm{WF} 100 \%)$ treatment.
It is observed from the data that minimum moisture content of cookies was observed in the cookies prepared from $100 \%$ wheat flour. Nwosu (2014) ${ }^{[12]}$, Sengev et al. (2015) ${ }^{[20]}$ and Rita and Essuman (2016) ${ }^{[19]}$ reported that cookies made from $100 \%$ wheat flour showed lowest moisture content. Moisture content of the cookies increased with increased in aerial yam 
flour. The results are in confirmation with the findings of Nwosu (2014) ${ }^{[12]}$, Chukwu and Lawal (2015) ${ }^{[7]}$, Sengev et al. $(2015)^{[20]}$ and Rita and Essuman (2016) ${ }^{[19]}$. This increased in moisture content brought about decreased in dry matter and might be due to the fact that initially aerial yam flour has high moisture content.

\section{Ash content (\%)}

The treatment $\mathrm{T}_{5}$ (AYF 100\%) showed maximum (1.76\%) ash which was found to be significantly superior over remaining treatments, while minimum $(1.10 \%)$ ash was recorded in $\mathrm{T}_{6}$ (WF100\%) treatment.

It is revealed from the data (table 2) that the ash content of cookies increased with the increase in supplementation of yam flour. This is in confirmation to the findings of Nwosu (2014) ${ }^{[12]}$ who observed that ash content of cookies decreased with the increase in percentage composition with wheat flour. This might be due to the high ash content of yam flour thus implies high mineral content in yam.

\section{Fat content (\%)}

The treatment $\mathrm{T}_{5}$ (AYF 100\%) showed maximum (25.64\%) fat which was found significantly superior over rest of the treatments, while minimum $(19.98 \%)$ fat was recorded in $\mathrm{T}_{6}$ (WF100\%) treatment.

It is well evident from the data presented in table 2 that fat content of the cookies made from wheat flour was minimum and gradually increased with the increase in aerial yam flour substitution in the composite flour. Similar results were observed by Chinma and Gernah (2007) ${ }^{[6]}$, Nwosu (2014) ${ }^{[12]}$ Laelago et al. (2015) ${ }^{[11]}$ and Rita and Essuman (2016) ${ }^{[19]}$. This might be due to the substitution effect of wheat flour with yam flour which contained more fat. The fat content of cookies might have significantly increased when formulated into cookies due to the added ingredients.

\section{Protein content (\%)}

The treatment $\mathrm{T}_{6}$ (WF 100\%) showed maximum (9.51\%) protein which was found to be significantly superior over remaining treatments, while minimum $(6.53 \%)$ protein was recorded in $\mathrm{T}_{5}(\mathrm{AYF} 100 \%$ ) treatment.

It is well evident from the data that the cookies prepared from the treatment $\mathrm{T}_{6}$ (WF 100\%) showed maximum protein content while $\mathrm{T}_{5}$ (AYF 100\%) with minimum protein content. The protein content continued to decrease as the proportion of aerial yam flour increased in the baked cookies. This might be due to low protein content of aerial yam. This is similar to the earlier findings of Oluwamukoni et al. (2011) ${ }^{[15]}$, Sengev et al. (2015) ${ }^{[20]}$ and Uchenna and Omolaya (2017) ${ }^{[24]}$. Oluwole and Karim (2005) ${ }^{[16]}$ and Olatunde et al. (2016) ${ }^{[14]}$ also reported greatest protein content in wheat flour and least in cassava which is poor source of protein.

\section{Crude fibre (\%)}

The treatment $\mathrm{T}_{5}$ (AYF 100\%) showed maximum $(1.75 \%)$ crude fibre which was found significantly superior over rest of the treatments, while minimum $(0.54 \%)$ crude fibre was recorded in $\mathrm{T}_{6}(\mathrm{WF} 100 \%)$ treatment.

It is observed from the data that, cookies produced from the treatment $\mathrm{T}_{5}$ (AYF 100\%) recorded highest crude fibre percentage while lowest in the treatment $\mathrm{T}_{6}$ (wheat flour $100 \%$ ). The crude fibre content increased with the increased of yam flour in composite flour. This is agreement with the findings of Nwosu (2014) ${ }^{[12]}$, Laelago et al. (2015) ${ }^{[11]}$ and Olatunde et al. (2016) ${ }^{[14]}$.

\section{Carbohydrate (\%)}

The treatment $\mathrm{T}_{6}$ (WF $100 \%$ ) showed maximum $(65.45 \%)$ carbohydrate which was found to be significantly superior over remaining treatments, while minimum $(58.49 \%)$ carbohydrate was recorded in $\mathrm{T}_{5}(\mathrm{AYF} 100 \%)$ treatment.

It is observed from the data that, the cookies prepared from $\mathrm{T}_{6}$ (WF 100\%) showed highest carbohydrate percentage while carbohydrate content continued to decrease as the proportion of aerial yam flour was increased in to baked cookies. This is in confirmity with the findings of Rita and Essuman (2016) ${ }^{[19]}$ who observed that increasing the proportion of aerial yam flour resulted in reduction of total carbohydrate which was further reduced by blanching. Similar results are reported by Chima and Gernah (2007) ${ }^{[6]}$ and Laelago et al. (2015) ${ }^{[11]}$.

\section{Sensory evaluation of cookies}

Data pertaining to the effect of different flour combination of aerial yam on appearance, taste, texture, flovour/aroma, crispiness and overall acceptability score of cookies are presented in Table 3 .

Table 3: Effect of different flour combination of aerial yam on sensory characteristics of cookies

\begin{tabular}{|c|c|c|c|c|c|c|}
\hline Treatment & Appearance & Taste & Texture & Flavour /aroma & Crispiness & Overall acceptability \\
\hline $\mathrm{T}_{1}$ (AYF 20\% + WF 80\%) & 6.9 & 7.3 & 6.5 & 5.5 & 7.3 & 6.7 \\
\hline $\mathrm{T}_{2}$ (AYF 40\% + WF 60\%) & 7.0 & 7.5 & 7.7 & 6.3 & 7.0 & 7.3 \\
\hline $\mathrm{T}_{3}$ (AYF 60\% + WF 40\%) & 8.3 & 8.0 & 8.0 & 7.5 & 7.0 & 8.3 \\
\hline $\mathrm{T}_{4}(\mathrm{AYF} 80 \%+$ WF 20\%) & 8.3 & 6.5 & 8.0 & 6.7 & 6.5 & 6.3 \\
\hline $\mathrm{T}_{5}(\mathrm{AYF} 100 \%)$ & 8.5 & 5.7 & 8.3 & 4.8 & 5.0 & 6.1 \\
\hline $\mathrm{T}_{6}$ (WF100\%) & 6.4 & 7.3 & 6.0 & 5.0 & 7.5 & 6.5 \\
\hline 'F' test & Sig. & Sig. & Sig. & Sig. & Sig. & Sig. \\
\hline SE(m) \pm & 0.08 & 0.05 & 0.04 & 0.03 & 0.04 & 0.07 \\
\hline CD at 5\% & 0.24 & 0.16 & 0.12 & 0.10 & 0.13 & 0.20 \\
\hline
\end{tabular}

\section{Appearance of cookies}

Appearance is an important sensory attribute of any food because of its influence on acceptability. It is an important parameter in judging properly baked cookies. The highest appearance score of 8.5 was obtained by the cookies $\left(\mathrm{T}_{5}\right)$ i.e. $100 \%$ aerial yam flour as compared to other treatments. The lowest score of 6.4 was obtained by cookies $\left(\mathrm{T}_{6}\right)$ i.e. $100 \%$ wheat flour. Increase in appearance score of the cookies was observed as the composition of the aerial yam flour increased.
The results are in contradictory to the findings of Nwosu (2014) ${ }^{[12]}$ who reported less score in appearance due to the characteristics colour of yam flour used as imparted by nonenzymatic browning during processing of yam flour.

\section{Taste of cookies}

Taste is an important sensory attribute of any food because of its influence on acceptability. It is observed from Table 3 that the taste score of cookies was significantly affected due to 
addition of different levels of aerial yam flour. Significant higher taste score was obtained in the cookies prepared from $\mathrm{T}_{3}$ (AYF 60\% + WF 40\%) while the lowest score in $\mathrm{T}_{5}$ (AYF $100 \%)$ as it resulted in slight bitter taste which comes from the natural taste of the yam flour used for preparation of cookies. The preferences for taste of the samples showed an increase with increasing substitution with yam flour upto $60 \%$. Similar results were reported by Abayomi et al. (2013).

\section{Texture of cookies}

It is observed that texture score of cookies was affected significantly due to addition of different levels of aerial yam flour.

Significantly highest score (8.3) was received to be cookies prepared with $100 \%$ aerial yam flour i.e. under $\mathrm{T}_{5}$ treatment while lowest score (6.0) was received by cookies prepared from $100 \%$ wheat flour i.e. $\mathrm{T}_{6}$. Increase in yam flour increased the texture score of the cookies. This could be due to the high moisture and fat content which resulted in soft texture of the cookies. Whereas, cookies made from 100\% wheat flour scored least due to its hard texture which may be due to less moisture content and fat content of cookies making it dry and hard. However, the present findings are in contradictory to the reports of Nwosu (2014) ${ }^{[12]}$ and Rita and Essuman (2016) ${ }^{[19]}$ who observed highest score for $100 \%$ wheat flour cookies. The variation in the findings may be due to the choice of panelist and their preference for the aerial yam cookies.

\section{Flavour/aroma}

Flavour is the main criteria that make the product to be liked or disliked. Supplementation of wheat flour to aerial yam flour upto $60 \%$ increased the texture score and these lowered down as the acridic flavor and aroma was not preferred by the panelist. Thus giving maximum score for flavor/ aroma to AYF $60 \%+$ WF $40 \%$ cookies. Inferior flavor of cookies made from $100 \%$ AYF $\left(\mathrm{T}_{6}\right)$ was not liked. Similar findings are reported by Sharif et al. (2009), Nwosu (2014) ${ }^{[12]}$ and Laelago et al. $(2015)^{[11]}$.

\section{Crispiness of cookies}

Significantly highest crispiness score (7.5) was obtained in cookies prepared with $100 \%$ wheat flour i.e. under $\mathrm{T}_{6}$ treatments which was superior over all the treatments while lowest crispiness score (5.0) was obtained in treatment $T_{5}$ (AYF 100\%). It was observed that the crispiness of the cookies increased as the proportion of aerial yam flour was decreased in the formulation. The present findings are similar to the findings of Nwosu (2014) ${ }^{[12]}$ and Rita and Essuman (2016) ${ }^{[19]}$. They also reported that crispiness was increased with decrease in yam flour. Nwosu (2014) ${ }^{[12]}$ reported decreased in crispiness due to high level of fat in yam flour which leads to low crispiness of cookies.

\section{Overall acceptability of cookies}

The appearance, taste and texture of the cookies, as well as their flavor and crispiness, all contributed to the general characteristics of the performance of the cookies. Overall acceptability score for the $100 \%$ yam flour and $100 \%$ wheat flour was less. Whereas the score tend to increase with the supplementation of yam flour to wheat flour up to $60 \%$ after which it again decreased. The results are in confirmation with the findings of Chinma and Gernah (2007) ${ }^{[6]}$ who reported that cookies made from composite flours were more acceptable than $100 \%$ wheat flour. This may be due to the enhancement attractive colour, flavor and taste imparted by the yam flour. The decline in acceptability at higher level of supplementation i.e. aerial yam flour $80 \%$ and $100 \%$ may be due to acridic and slight bitter taste and flavor originating from yam flour. However the supplementation of aerial yam flour to wheat flour was accepted upto $60 \%$. Kayode et al. (2017) also confirmed the supplementation of $60-80 \%$ of aerial yam flour for use in flour formulations for desirable sensory characteristics.

\section{Summary}

Protein and carbohydrate content of prepared cookies were decreased with higher replacement of aerial yam flour. Moisture, ash, fat and crude fibre content of cookies was increased with higher replacement of aerial yam flour to the wheat flour.

Sensory evaluation revealed that, the score for appearance, taste and texture of cookies increased with increasing aerial yam flour in substitution to wheat flour while crispiness was reduced. Flavour/aroma and overall acceptability of cookies was increased with the addition of more aerial yam flour upto 60 per cent, making it most acceptable for cookies.

Cookies prepared with 60 per cent aerial yam flour and 40 per cent wheat flour was found to be most acceptable with respect to organoleptic characteristics especially taste and flavour/aroma developed during baking.

\section{Conclusions}

Aerial yam flour can be used for substitution of wheat flour upto 60 per cent with maximum acceptability by the consumers. The results obtained showed the feasibility of producing nutritious cookies from aerial yam flour. This study has indicated that acceptability and nutritious cookies would be prepared from the composite flour of aerial yam and wheat.

These results can be further applied for the development of nutritious and high fibre cookies. The above conclusion is however based on the laboratory study and hence is suggestive.

\section{References}

1. AACC. Official methods of analysis. American Association of cereal Chemists (10th ed.) The Association INC. St., Paul, Minnesota, USA, 2000.

2. AOAC. Official methods of analysis ( $16^{\text {th }}$ Edn.) Artington, V.A, Association of Official Analitical Chemists, 1995, 806-842.

3. Abara AE, Udosen EO, Eka OU. Estimation of calcium, zinc, hydrocyanate oxalate and phytate in Dioscorea bulbifera tuber. Global J Pure Applied Sci. 2000; 6:449453.

4. Abayomi HT, Oresanya TO, Opeifa AO, Rasheed TR. Quality evaluation of cookies produced from blends of sweet potato and fermented soybean flour. International J. Biological, Biomolecular, Agricultural, Food and Biotechnological Engineering. 2013; 7(7):639-644.

5. Amerine MA, Pangborn RM, Rossler EB. Principles of Sensory Evaluation of Food. Acedemic Press. New York, 1965, 350-376.

6. Chinma CE, Gernah DI. Physicochemical and sensory properties of cookies produced from cassava/soybean/mango composite flours. J Food Tech. 2007; 5(3):256-260.

7. Chukwu O, Lawal AO. Comparative study of storage stability of sweet potato and yam flours. International 
Jiurnal of Engineering Technologies in Engineeging Research. 2015; 3(3):44-49.

8. Ihekoronye AT, Ngoddy PO. Integrated Food Science and Technology for the Tropics. Mc Millian Pulblisher Limited, London. 1985; 266-282:366-368.

9. Jayakody L, Hoover R, Liu Q, Donner E. Studies on tuber starches, Molecular structure, composition and physicochemical properties of yam (Dioscorea sp.) starches grown in Sri Lanka. Carbohydrate Polymers. 2007; 69:148-163.

10. Kayode RMO, Buhari OJ, Otutu LO, Ajibola TB, Oyeyinka SA et al. Physiochemical properties of processed aerial yam (Dioscorea bulbifera) flour and sensory properties of paste (Amala) prepared with cassava flour. The Journal of Agriculture Sciences. 2017; 12(2):84-94.

11. Laelago T, Haile A, Fekadu T. Production and quality evaluation of cookies enriched with $\beta$ - carotene by blending orange-fleshed sweet potato and wheat flours for alleviation of nutritional insecurity. International $\mathrm{J}$ Food and Nutrition Engineering. 2015; 5(5):209-217.

12. Nwosu JN. Evaluation of the proximate and sensory properties of biscuits produced from aerial yam flour (Dioscorea bulbifera). American J Research Communication. 2014; 2(3):119-126.

13. Ojinnaka MC, Odimegwu EN, Ilechukwu R. Functional properties of flour and starch from two cultivars of aerial yam (Dioscorea bulbifera) in South East Nigeria. IOSR Journal of Agriculture and Veterinary Science. 2016; $9(8): 22-25$

14. Olatunde SJ, Oyeyinka SA, Adetola RO, Oyeyinka AT, Owolabi TO. Physicochemical properties of pro-vitamin A cassava-wheat composite flour biscuit. Food in Health and Disease, Scientific- Professional J Nutrition and Dietetics. 2016; 5(1):20-26.

15. Oluwamukomi MO, Oluwalana IB, Akinbowale OF. Physicochemical and sensory properties of wheatcassava composite biscuit enriched with soy flour. African J Food Sci. 2011; 5(2):50-56.

16. Oluwole OB, Karim OR. Production of biscuits from bambara, cassava and wheat flour blends. J. Raw Material Research. 2005; 2(1):34-38.

17. Otoo E, Asiedu R. GGE biplot analysis of Dioscorearotundata cultivar "Dente" in Ghana. African Journal of Agricultural Resolution. 2008; 3:115-125.

18. Panse VG, Sukhatm PV. Statistical Methods for Agricultural Workers. ICAR, New Delhi, 1985, 70-72.

19. Rita Sanful E, Essuman EK. Effect of blanching on the proximate and sensory qualities of the aerial yam composite cookies. Carib. J Sci. and tech. 2016; 4:963968.

20. Sengev IA, Gernah DI, Bunde-Tsegba MC. Physical, chemical and sensory properties of cookies produced from sweet potato and mango mersocarp flours. African J. Food, Agriculture, Nutrition and Development. 2015; 15(5):1.

21. Sharma R. Agro-technique of medicinal plants. Daya Publishing House, New Delhi, 2004, 81-82.

22. Subasini U, Thenmozhi S, Sathyamurthy D,Vetriselvan S, Rajamanickam GV, Dubey GP. Pharmagonostic and Phytochemical Investigation of Dioscorea bulbifera. Int. J Pharm. And Life Sci. 2013; 4(5):2693-2700.

23. Tindall HD. Vegetables in the tropics. $1^{\text {st }}$ Edn., Macmillan Education Ltd. Houndmills, Hampsgire, 1983, 207-221.
24. Uchenna CJ, Omolaya FT. Development and quality evaluation of biscuits formulated from flour blends of wheat, bambara nut and aerial yam. Annals. Food Science and Technology. 2017; 18(1):51-56.

25. Zannou A. Socio-economic, agronomic and molecular analysis of yam and cowpea diversity in the GuineaSudan transition zone of Benin. Ph.D. Thesis, Wageningen University, 2006. 